\title{
Evaluation of Methyl Iodide for Control of Peach Replant Disorder
}

\author{
C. G. Eayre, USDA Agricultural Research Service, 2021 S. Peach Ave. Fresno, CA 93727; J. J. Sims and H. D. \\ Ohr, Department of Plant Pathology, University of California, Riverside 92521; and B. Mackey, USDA Agricul- \\ tural Research Service, 800 Buchanan St., Albany, CA 94710
}

\begin{abstract}
Eayre, C. G., Sims, J. J., Ohr, H. D., and Mackey, B. 2000. Evaluation of methyl iodide for control of peach replant disorder. Plant Dis. 84:1177-1179.

Peach replant soils were fumigated with methyl bromide (MB) or methyl iodide (MI) at rates of 392 to $448 \mathrm{~kg} / \mathrm{ha}$. In two trials, peach tree growth in fumigated soil or in untreated soil was evaluated by measuring trunk diameter and weight of branches removed by pruning. In both trials, trunk diameter of trees grown in MB- and MI-fumigated plots was greater than trees in control plots $(P \leq 0.01)$. In both trials, weight of branches pruned from trees grown in fumigated plots was greater than branch weights from trees grown in control plots $(P \leq 0.01)$. Plots fumigated with MI did not differ from plots fumigated with MB in trunk growth, weight of branch prunings, or reductions in population densities of the nematode Paratylenchus. MI and MB appeared to be equally effective in controlling replant disorder.
\end{abstract}

Peach replant disorder occurs when a new orchard is planted in soil that has recently been in peach production. Trees in a replant disorder site have reduced growth and produce leaves that are light green to yellow-green rather than dark green. Fruit production is delayed and yields are reduced. Economic losses continue for the life of the orchard $(8,9)$. Factors associated with peach replant disorder include poor soil structure, extremes of soil $\mathrm{pH}$, poor nutrition, cyanide produced during the microbial breakdown of prunasin in old peach roots, several fungi and nematodes, and lack of vesicular-arbuscular mycorrhizal fungi $(4,8,9)$. However, no single factor or interactions of the identified factors have been shown conclusively to cause replant disorder.

Preplant soil fumigation with methyl bromide (MB) controls replant disorder and is currently used when new stone fruit orchards or single trees are being replanted on previous orchard sites $(8,9)$. Since methyl bromide has been classified as a chemical that contributes to depletion of the Earth's ozone layer, production and importation of MB in the United States are scheduled to be phased out by 2005 , with only critical agricultural uses allowed after 2005. Currently, there is no single chemical alternative to methyl bromide for preplant soil fumigation use.

Corresponding author: C. G. Eayre

E-mail: ceayre@asrr.arsusda.gov

Accepted for publication 5 July 2000.

Publication no. D-2000-0830-01R

This article is in the public domain and not copyrightable. It may be freely reprinted with customary crediting of the source. The American Phytopathological Society, 2000.
Because of its similar chemical reactivity, methyl iodide (MI) has been suggested as an alternative fumigant to replace MB (11). MI has been shown to have the same broad-spectrum efficacy against fungi, nematodes, insects, and weeds as MB $(1,5,7,12,14,15)$. Unlike MB, MI is rapidly destroyed by ultraviolet light near the Earth's surface and thus does not reach the stratosphere where damage to the ozone layer by halogenated hydrocarbons occurs. MI is a liquid at ambient temperature and standard atmospheric pressure, with a boiling point of $42.5^{\circ} \mathrm{C}$, while $\mathrm{MB}$ is a gas with a boiling point of $3.6^{\circ} \mathrm{C}$. This latter property should result in greater worker safety during handling of MI as compared to handling the compressed gas, MB. As would be expected from its physical and chemical properties, MI has been shown to behave very much like MB when applied to the soil subsurface (3). MI, however, has not been extensively tested as a soil fumigant under field conditions (6). The objective of this research was to determine the efficacy of MI and compare its performance with MB for managing peach replant disorder in California.

\section{MATERIALS AND METHODS}

Site preparation. All sites had been cropped in peaches, and previous trees were removed not more than 6 months prior to spring planting of test trees. The trials were on a Hanford fine sandy loam soil with silty substratum at adjacent sites in Parlier, CA. The experiments were run twice, and each included four replications in a randomized complete block design. In the first trial, the plots (experimental units) were $3.4 \mathrm{~m}$ wide and $30.5 \mathrm{~m}$ long, and contained one row of 10 trees planted $3 \mathrm{~m}$ apart in 1997. Plots in the second trial were $16.5 \times 19.2 \mathrm{~m}$ and contained 25 trees planted in 5 rows of 5 trees, planted $3 \mathrm{~m}$ apart in 1998.

Prior to fumigation, the soil in both treatment and control plots was prepared by ripping to remove large roots from the previous crop, followed by harrowing and discing. Soil fumigation was performed by a commercial applicator (Tri-Cal Inc., Hollister, CA), using a Caterpillar D4E modified for fumigation. MI or MB was injected by two $61-\mathrm{cm}$ shanks spaced 152 $\mathrm{cm}$ apart, with plastic tarp $(0.001 \mathrm{~mm}$ clear high barrier film, Cadillac Products, Inc., Rogers City, MI) applied simultaneously as the fumigant was injected. In the first trial, $\mathrm{MI}$ and MB were each applied at $448 \mathrm{~kg} / \mathrm{ha}$ on 28 April 1997 (soil temperature $15^{\circ} \mathrm{C}$ ). In the second trial, both fumigants were applied at $392.34 \mathrm{~kg} / \mathrm{ha}$ on 20 November 1997 (soil temperature $14^{\circ} \mathrm{C}$ ). The soil was slightly moist, water potential approximately -15 to -20 centibars, as is normal for MB fumigation. Barrier film was removed 7 to 10 days later. MB contained $0.5 \%$ chloropicrin, the lowest concentration of chloropicrin marker available, and the standard rate for use in commercial replant situations. MI did not contain chloropicrin. At $0.5 \%$, chloropicrin functions as a marker for worker safety rather than as a fungicide.

Replants and assessment of tree growth. Grafted, bare root 1-year-old trees of peach cv. O'Henry on Nemaguard rootstock were purchased from commercial nurseries (The Burchell Nursery, Fowler CA; Dave Wilson Nursery, Hickman, CA) and planted on 15 May 1997 and 2 March 1998 in the first and second trials, respectively. Trees of uniform size were used for a given experiment. To minimize the confounding effects of weed growth in nonfumigated control plots, weeds were controlled in all plots by hand hoeing, mowing, and herbicide sprays. Trunk diameter was measured $30.5 \mathrm{~cm}$ from soil level with calipers at the end of the growing seasons. Data from the two trials were combined for analyses of variance and the treatment means compared using least squares means and $95 \%$ confidence intervals (Version 6.12, SAS Institute, Cary, NC). Trunk diameters were transformed by reciprocal square roots prior to analysis to stabilize the variances among years and treatments. Bartlett's homogeneity of variance test was nonsignificant for both transformed trunk diameter $(P=0.66)$ and weight of pruned branches $(P=$ $0.76)$. 
Trees were pruned to three scaffold branches according to standard horticultural practices during the dormant winter season. Pruned branches were weighed and the results subjected to analysis of variance as described above. All treatments were pruned on the same day.

Evaluation of nematode populations. Soil samples were analyzed for nematode genera and population density. Samples were taken in August in the first trial and every six weeks in the second trial. Nematodes were extracted from a $400-\mathrm{cm}^{3}$ soil subsample with a modified semiautomatic elutriator and sucrose centrifugation technique (2). Nematodes were counted and soil populations calculated.

\section{RESULTS}

Since the results of the two trials and an earlier preliminary trial (data not shown) were very similar, the data from the two trials reported here were combined. Trunk diameters of trees grown in soil treated with MI or MB averaged larger than those grown in nontreated plots (Table 1). This difference was evidenced for both years despite significance of the year $\times$ treatment interaction. Similarly, the weight of branches pruned from trees grown in fumigated plots was greater than those grown in nonfumigated plots (Table 1). For both measures, the confidence intervals overlap when comparing trees grown in soil treated with MB versus those grown in soil fumigated with MI. In addition to measurable differences, there was a visual difference between trees grown in fumigated versus nonfumigated plots (Fig. 1).

No nematodes were found in plots treated with MI or MB plots. In control plots however, counts of Paratylenchus sp. averaged 525 per liter of soil in August 1997, 3 months after planting in the first trial, and 2,288 per liter of soil in nontreated control plots in May 1998, 3 months after planting in the second trial. Nematode populations were similar on other sampling dates (data not shown).

\section{DISCUSSION}

In vitro tests indicated that MI is very effective in control of soilborne plant pathogens (11). These field results are consistent with laboratory studies on the efficacy of MI. These studies show that MI is comparable to MB. Control of early stages of replant disorder of peaches is not significantly different from that achieved with $\mathrm{MB}$, and the equipment used is the same. Other proposed alternatives to $\mathrm{MB}$ have limitations on use and may be effective in one situation but not another, or are simply not as effective.

Although MI's lower volatility may make it safer to handle than $\mathrm{MB}$, safety

Table 1. Least squares means and $95 \%$ confidence intervals for trunk diameters $(\mathrm{mm})$ and weight of branches pruned $(\mathrm{kg})$ from trees planted in plots fumigated with methyl bromide (MB) or methyl iodide (MI) and nonfumigated plots ${ }^{z}$

\begin{tabular}{lccc}
\hline & MB & MI & Control \\
\hline Trunk diameter (1997) & $56.2(48.4,66.0)$ & $51.8(44.9,60.5)$ & $32.8(29.2,37.0)$ \\
Trunk diameter (1998) & $25.3(22.9,28.2)$ & $22.7(20.6,25.1)$ & $15.2(14.0,16.5)$ \\
Weight of pruned branches & $51.9(45.5,58.2)$ & $42.8(36.4,49.1)$ & $18.0(11.6,24.3)$ \\
\hline
\end{tabular}

${ }^{\mathrm{z}}$ The results of both trials were combined for statistical analysis. The year $\times$ treatment interaction was significant for trunk diameter $(P=0.036)$ but nonsignificant for weight of pruned branches $(P$ $=0.87$ ). The means are of results from four replicates per year, ten trees per experimental unit.

precautions taken during application of MI should be similar to those taken during the application of MB .

$\mathrm{MI}$ is not registered with the EPA as a pesticide. Additional field testing will be needed to determine the lowest effective rates for use of MI. Although it is expected that MI would also be effective for other crops, such as other stone fruit and strawberries, it should be tested on those crops. Use of low permeability plastic films may also allow a lower rate of MI to be used by retaining the gas in the soil. MB is most commonly used in combination with chloropicrin because of synergism between the two against fungi $(10,13)$. Recently published data show a similar synergism with a combination of chloropicrin and MI (7).

Additional studies are also needed on the etiology of replant disorder of stone fruit. In this case, only low levels of weakly parasitic nematodes were found and are not believed to be the cause of replant disorder. It is not clear what pathogen, or combination of pathogens and environmental factors, caused the reduced growth at this site. The cause or causes of replant disorder have not been conclusively determined. On sites with sandy soils, nematodes are associated with replant problems such as increased occurrence of bacterial canker. However, these pathogens are not identified on all replant sites. Different biotic or abiotic factors or combinations thereof may be involved at different sites. With MB fumigation, it has been possible to control peach replant disorder without determining its causes. The loss of MB brings attention to the need to understand the etiology of the peach replant disorder. Extensive research remains to be done on replant disorder. The soil in plots of these trials will be useful for comparison with other replant disorder sites and

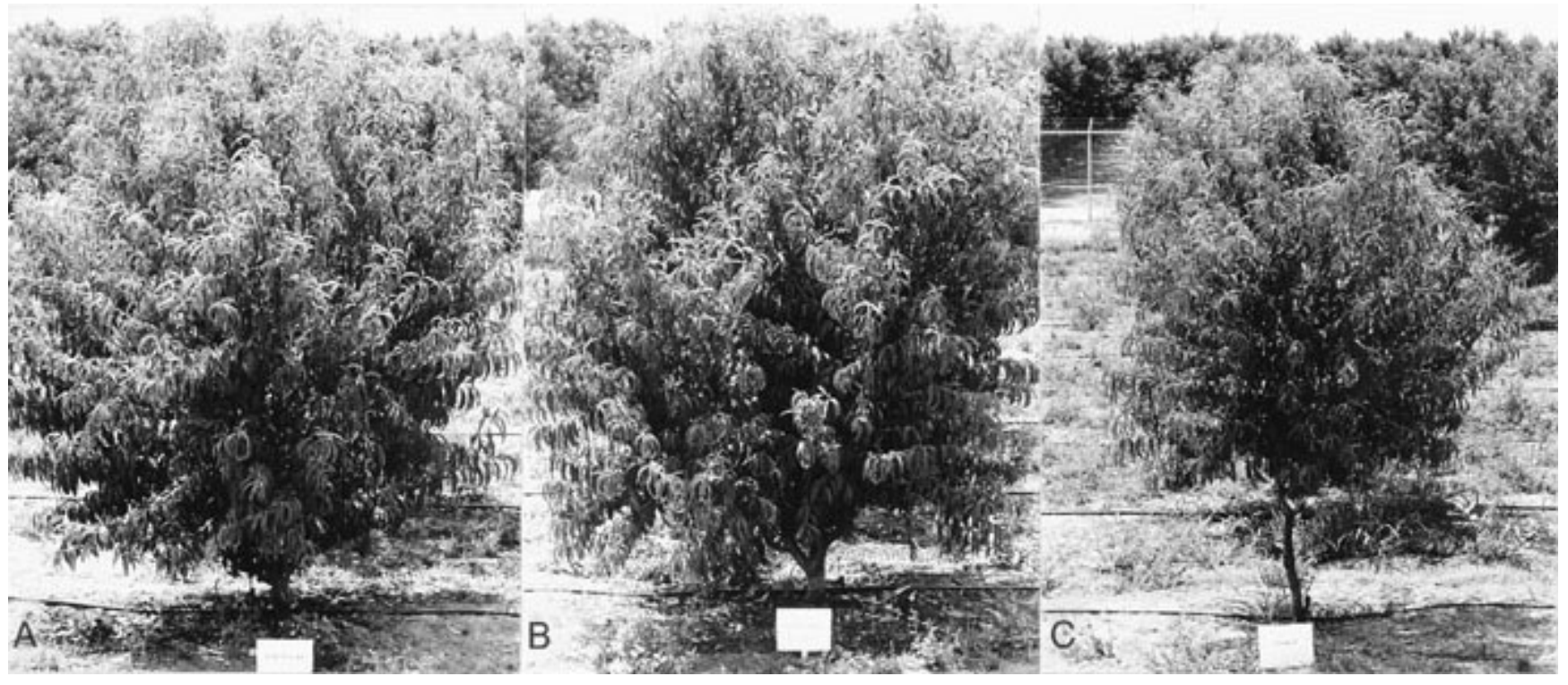

Fig. 1. Appearance of trees in the second growing season following fumigation with (A) methyl bromide, (B) methyl iodide, or (C) in nonfumigated soil. 
further research to determine the etiology of peach replant disorder.

\section{ACKNOWLEDGMENTS}

We thank Tri-Cal and the United States EPA for partial support.

\section{LITERATURE CITED}

1. Becker, J. O., Ohr, H. D., Grech, N. M., McGiffen, M. E., Jr., and Sims, J. J. 1998. Evaluation methyl iodide as a soil fumigant in container and small field plot studies. Pestic. Sci. 52:58-62.

2. Byrd, D. W., Jr., Barker, K. R., Ferris, H., Nusbaum, C. J., Griffin, W. E., Small, R. H., and Stone, C. A. 1976. Two semi-automatic elutriators for extracting nematodes and certain fungi from soil. J. Nematol. 8:206-212.

3. Gan, J., Yates, S. R., Ohr, H. D., and Sims, J. J. 1997. Volatilization and distribution of methyl iodide and methyl bromide after subsoil application. J. Environ. Qual. 26:11071115.

4. Gur, A., and Cohen, Y. 1988. Causes of soil sickness in replanted peaches: 1 . The role of cyanogenesis in peach soil sickness. Acta Hort. 233:25-31
5. Hutchinson, C., McGiffin, M. E., Ohr, H. D., Sims, J. J., and Becker, J. O. 1999. Efficacy of methyl iodide soil fumigation for control of Meloidogyne incognita, Tylenchulus semipenetrans, and Heterodera schachtii. Nematology 1:407-414.

6. Hutchinson, C., McGiffin, M. E., Ohr, H. D., Sims, J. J., and Becker, J. O. 1999. Evaluation of methyl iodide as a soil fumigant for rootknot nematode control in carrot production. Plant Dis. 83:33-36.

7. Hutchinson, C. M., McGiffen, M. E., Jr., Ohr, H. D., Sims, J. J., and Becker, J. O. 2000. Efficacy of methyl iodide and synergy with chloropicrin for control of fungi. Pest Manage. Sci. 56:1-6.

8. Larsen, H. J. 1990. Countering orchard replant problems. Proc. W. Colo. Hort. Soc. 47:46-56.

9. Larsen, H. J. 1995. Replant Disorders. Pages 4647 in: Compendium of Stone Fruit Diseases. J. M. Ogawa, E. I. Zehr, G. W. Bird, D. F. Ritchie, K. Uriu, and J. K. Uyemoto, eds. American Phytopathological Society, St. Paul, MN

10. Munnecke, D. E., Kolbezen, M. J., and Bricker, J. L. 1982. Effects of moisture, chloropicrin, and methyl bromide singly and in mixtures on sclerotia of Sclerotium rolfsii and Verticillium albo-atrum. Phytopathology 72:1235-1238.

11. Ohr, H. D., Sims, J. J., Grech, N. M., Becker, J. O., and McGiffen, M. E., Jr. 1996. Methyl iodide, an ozone-safe alternative to methyl bromide as a soil fumigant. Plant Dis. 80:731735 .

12. Waggoner, M., Ohr, H. D., Adams, C., Sims, J. J., and Gonzalez, D. 2000. Methyl iodide an alternative to methyl bromide for insectary fumigation. J. Appl. Ent. In press.

13. Wilhelm, S., Storkan, R. C., and Sagen, J. E. 1961. Verticillium wilt of strawberry controlled by fumigation of soil with chloropicrin and chloropicrin-methyl bromide mixtures. Phytopathology 51:744-748.

14. Zhang, W., McGiffen, M. E., Jr., Becker, J. O. Ohr, H. D., Sims, J. J., and Campbell, S. D. 1998. Effects of soil physical factors on methyl iodide and methyl bromide fumigation. Pest. Sci. 53:71-79.

15. Zhang, W. M., McGiffen, M. E., Jr., Becker, J. O., Ohr, H. D., Sims, J. J., and Kallenbach, R. L. 1997. Dose response of weeds to methyl iodide and methyl bromide. Weed Res. 37:181-189. 